\title{
Effects of changes in precipitation on energy and water balance in a Eurasian meadow steppe
}

\author{
Jingyan Chen ${ }^{1} \mathbb{D}$, Changliang Shao ${ }^{2}$, Shicheng Jiang ${ }^{3}$, Luping Qu ${ }^{4}$, Fangyuan Zhao, ${ }^{5,6}$ and Gang Dong ${ }^{7,2^{*}}$
}

\begin{abstract}
Introduction: Water such as precipitation is the most critical environment driver of ecosystem processes and functions in semi-arid regions. Frequency and intensity of drought and transient waterlogging are expected to increase in the meadow steppe in northeastern China. Using a 4-year dataset of eddy covariance flux measurements, ground measurements of biomass, phenology, and meteorological conditions, we investigated the changes in energy fluxes at multiple temporal scales and under different precipitation regimes.

Results: The meadow steppe was latent heat (LE) dominated when soil water content was $>0.3 \mathrm{~m}^{3} \mathrm{~m}^{-3}$, but switched to sensible heat $(H)$ dominated status when soil water content fell below $0.3 \mathrm{~m}^{3} \mathrm{~m}^{-3}$. LE dominated the energy exchange of the meadow grasslands on a yearly basis. Intensive precipitation had a profound impact on water-energy balance that could reduce the damages of drought by elevating deep soil moisture. The influence of LE on waterlogging depended on timing, with increased LE at the beginning of growing season and decreased LE after waterlogging. Spring and summer droughts resulted in different energy partitioning between latent and sensible heat energies, with spring drought dramatically decreased the LE fraction due to the change in water. In contrast, summer drought had little impact on LE due to the sufficient water input from large precipitation events at the beginning of the growing season.

Conclusions: There existed great seasonal and interannual variabilities in energy balance and partitioning in the meadow steppe over the 4-year study period, which were strongly influenced by changes in precipitation. The water loss through latent heat was more sensitive to spring drought than to summer drought, while summer drought had negligible impact on LE. Waterlogging contributed to LE by enhancing its values during and after the waterlogged periods at the beginning of the growing season in a dry year, but lowering its value after the waterlogged periods in growing season.
\end{abstract}

Keywords: Energy balance, Energy partition, Precipitation change, Eddy covariance, Drought

\section{Introduction}

Water is the most influential resource in ecosystems and societies in arid and semi-arid areas (Chen et al. 2013; Feng et al. 2016; Jaeger et al. 2017; Qi et al. 2017). In drylands, the spatio-temporal distribution and availability of water resources have been the major focuses of terrestrial ecosystem studies at local, regional and global

\footnotetext{
* Correspondence: dongg@sxu.edu.cn

${ }^{7}$ School of Life Science, Shanxi University, Taiyuan 030006, China

${ }^{2}$ National Hulunber Grassland Ecosystem Observation and Research Station \& Institute of Agricultural Resources and Regional Planning, Chinese Academy of Agricultural Sciences, Beijing 100081, China

Full list of author information is available at the end of the article
}

levels (Groisman et al. 2017; Monier et al. 2017; Soja and Groisman 2018). In terrestrial ecosystems, hydrological cycling is largely motivated through energy transfer because of the close coupling of water and heat. Precipitation, via either rainfall or snow, is the largest flux term of water budget and can lead to changes in soil moisture and latent heat (LE), sensible heat $(H)$, soil heat flux $(G)$, and heat storage $(S)$ by influencing plant transpiration and soil evaporation (Rodrigues et al. 2013). Knowledge about coupled ecosystem water cycling and energy balance can not only be applied to explain the integrated water-energy exchange between ground and 
atmosphere but also be used to address water scarcity and maintain ecosystem functions.

Rapid changes in land use and land cover and global warming have produced an increasing incidence and intensity of climatic extremes such as frequent and heavy precipitation events (Eade et al. 2012; IPCC 2013; Rey et al. 2017) and more intensive and prolonged drought. Changes in precipitation regimes contribute to higher uncertainty in ecosystem water-energy balance that requires further investigation of biomes and habitat. For instance, Minderlein and Menzel (2015) reported direct influences of precipitation on soil moisture, evapotranspiration (ET), and energy balance of shrubgrass ecosystems in the semi-arid areas of northern Mongolia. Nevertheless, there remains limited knowledge and consensus on the relationships between changes in precipitation and water-energy balance in grassland ecosystems.

Climate change, together with human disturbances, has had a large influence on ecological processes in the Eurasian Steppes, such as carbon assimilation and emission and energy and hydrological cycling. The meadow steppe appears to be the most sensitive ecosystem type in the grassland biome because of its relatively high biodiversity and high demands for water (Wang et al. 2007). Using a long-term research site of a meadow steppe in Northeast China, we explore the changes over time in water and energy fluxes in response to changes in climate, especially precipitation. Here, we focus particularly on the changes of major energy flux terms and the overall balances under different water availability. Based on 4 years of eddy covariance measurements, we first emphasize the distribution of energy and water fluxes and the possible ecological and climatological controls for a Songnen meadow steppe. Precipitation and its extremes, especially drought and transient waterlogging events, are examined for their roles in regulating the energy balance. Two major scientific questions are as follows: (1) What are the roles of shifting precipitation on water-energy balance of a meadow steppe? (2) What are the differences in how each energy flux term responds to spring/summer drought and transient waterlogging?

\section{Materials and methods \\ Study site}

This study was conducted at the Songnen Grassland Ecology Field Station of the Northeast Normal University (NENU) in Changling, Jilin, China $\left(123^{\circ} 30^{\prime} \mathrm{E}, 44^{\circ}\right.$ $35^{\prime} \mathrm{N}, 171 \mathrm{~m}$ a.s.l.). The site is representative of a temperate meadow steppe dominated by perennial grasses, including Leymus chinensis and Phragmitis communis. The study area has a temperate, semi-arid continental monsoonal climate, with a cold-dry spring and a warmwet summer. The mean annual temperature is $5{ }^{\circ} \mathrm{C}$, with the maximum and minimum temperatures being $39.2{ }^{\circ} \mathrm{C}$ and $-33.9{ }^{\circ} \mathrm{C}$, respectively. The frost-free period is approximately 130 days to 165 days. The precipitation varied greatly within and between years, with an annual mean of $350 \mathrm{~mm}, 80 \%$ of which falls between June and August. The annual pan evaporation varies from 1200 to $1600 \mathrm{~mm}$, which is approximately three to four times higher than the mean annual precipitation. The growing season runs from May through September. Main soil types in this area are alkaline soil, chernozem, and saline soil.

\section{Flux measurements}

To evaluate the energy and water exchanges between the land surface and the atmosphere, an open-path eddy-covariance (EC) flux tower was deployed in 2007 as part of the US-China Carbon Consortium (USCCC). A three-dimensional ultrasonic anemometer (CSAT3, Campbell Scientific Inc. (CSI)) and a $\mathrm{CO}_{2} / \mathrm{H}_{2} \mathrm{O}$ infrared gas analyzer (LI-7500, LI-COR) were mounted $2 \mathrm{~m}$ above the ground. Fluxes were calculated as the mean covariance of vertical wind speed fluctuation and the scalar fluctuation. Downward fluxes were indicated as negative and upward as positive. All raw data was sampled at $10 \mathrm{H}_{\mathrm{z}}$ and logged using a CR3000 data-logger (CSI). Footprint analysis using the flux source area model (FSAM) suggested a footprint in the prevalent wind direction $\left(150-240^{\circ}\right)$ extended to approximately $6.5 \mathrm{~m}$ to $77.8 \mathrm{~m}$ during unstable conditions (Monin-Obukhov length $(L)<0)$ and to about $11.3 \mathrm{~m}$ to $229.9 \mathrm{~m}$ during stable conditions $(L>0)$ at night, representing $90 \%$ of the total flux.

\section{Meteorological measurements}

Meteorological measurements were taken starting in May 2007. Net radiation $\left(R_{\mathrm{n}}\right)$ was measured using a four-component net radiometer (CNR-1, Kipp \& Zonen) at $2 \mathrm{~m}$ above the ground. Photosynthetically active radiation (PAR), precipitation (P), wind speed (WS), and wind direction (WD) were measured by a quantum sensor (LI190SB, LI-COR), a tipping-bucket rain gauge (TE525MM, CSI), and a propeller anemometer (034B-L Met One Windset, CSI), respectively. Air temperature $\left(T_{\mathrm{a}}\right)$ and relative humidity $\left(R_{\mathrm{h}}\right)$ were measured at 2,4 , and $6 \mathrm{~m}$ with HMP45C probes (Vaisala). Soil temperature profiles $\left(T_{\mathrm{S}}\right)$ were measured at depths of $0.05,0.1$, and $0.3 \mathrm{~m}$ below the ground by thermistors (107-L, CSI). Soil heat flux $(G)$ was measured at a depth of $0.05 \mathrm{~m}$ in three separate locations (HFT-3, REBS), and soil water content (SWC) was measured at a depth of $0.1 \mathrm{~m}$ by a time-domain reflectometry probe (CS616, CSI), which was buried horizontally in the soil. Additionally, soil water potential (SWP) was estimated using watermark probes at 0.1 and $0.3 \mathrm{~m}$ (257-L, CSI). All micrometeorological data were 
recorded and averaged or summed over a 30-min interval by a separate CR3000 data-logger.

\section{Vegetation}

Biometric measurements of aboveground biomass (AGB), vegetation height $(\mathrm{Vt})$, and leaf area index (LAI) were conducted monthly during the growing season (May to September). Within a radius of $200 \mathrm{~m}$ around the EC tower, we placed $120.5 \mathrm{~m}^{2}$ quadrats for measuring Vt and LAI by a plant canopy analyzer (LAI-2000, LI-COR), while AGB was destructively sampled in 12 additional $0.5 \mathrm{~m}^{2}$ quadrats.

\section{Data processing and gap filling}

The EC flux data was processed using EdiRe. The planar fit rotation and Webb-Pearman-Leaning (WPL) density correction were applied to the flux calculations (Webb et al. 1980). Data from stable nocturnal periods were excluded, specifically when the friction velocity $\left(u^{\prime \prime}\right)$ was $<0.15 \mathrm{~m} \mathrm{~s}^{-1}$. Anomalous or spurious data due to sensor malfunction, sensor maintenance, precipitation events, IRGA calibration, and power failure were also rejected. Consequently, $25.4 \%, 20.9 \%, 27.1 \%$, and $30.6 \%$ of the data obtained during growing season in 2007, 2008, 2009 , and 2010, respectively, were discarded. The introduced data gaps were filled with following the methods: for gaps of less than $2 \mathrm{~h}$, linear interpolation was used by averaging the fluxes before and after the gaps; for larger data gaps, we used both the empirical relationships and look-up tables (Falge et al. 2001).

\section{Calculation of soil heat storage}

The $R_{\mathrm{n}}$ was partitioned into convective $H$ for heating the atmosphere, LE for evaporating water from plants and the soil, $G$ for heating the soil, and $S$ for heat storage in the soil. Because the canopy and air heat storage are expected to be negligible in short canopies with minimal biomass, the canopy heat storage was not included in our energy balance algorithm:

$$
R_{n}=H+\mathrm{LE}+\mathrm{G}+S
$$

where soil heat storage $(S)$ was calculated as follows:

$$
S=C_{s} \frac{\Delta T_{s}}{\Delta t} d
$$

where $T_{s}$ is the average soil temperature $(\mathrm{K})$ above heat flux plates, $t$ is time $(\Delta t=1800 \mathrm{~s}), d$ is a depth between the heat flux plate and soil surface, and $C_{s}$ is the soil heat capacity calculated from Shao et al. (2014):

$$
C_{s}=\rho_{b} C_{d}+\theta_{v} \rho_{w} C_{w}
$$

where $\rho_{b}$ is soil bulk density, $\rho_{w}$ is the density of water, $C_{d}$ and $C_{w}$ are the specific heat capacity of dry mineral soil $\left(C_{d}=890 \mathrm{~J} \mathrm{~kg}^{-1} \mathrm{~K}^{-1}\right)$ and soil water $\left(C_{w}=4190 \mathrm{~J} \mathrm{~kg}^{-1} \mathrm{~K}^{-1}\right)$, respectively, and $\theta_{v}$ is volumetric SWC (\%). The heat storage of air and organic matter in the soil were neglected due to their small quantities.

\section{Energy parameters}

The energy balance ratio (EBR) was calculated as a ratio of the turbulent fluxes $(\mathrm{LE}+H)$ and the radiative energy fluxes $\left(R_{\mathrm{n}}-G-S\right)$ :

$$
\mathrm{EBR}=\frac{\sum(L E+H)}{\sum\left(R_{n}-G-S\right)}
$$

Canopy conductance $\left(g_{\mathrm{c}}\right)$ was calculated using the inverted form of the Penman-Monteith equation (Monteith and Unsworth 1990):

$$
g_{c}=\frac{1}{\frac{\rho C_{p}}{\gamma} \frac{D}{L E}+\left(\frac{\Delta}{\gamma} \frac{H}{L E}-1\right) / g_{a}}
$$

where $\rho$ is air density, $C_{\mathrm{p}}$ is the specific heat of the air, $\Delta$ is the change of saturation vapor pressure with temperature, $\gamma$ is the psychrometric constant, $D$ is the vapor press deficit of air, and $g_{\mathrm{a}}$ is the aerodynamic conductance of the air layer between the canopy and the flux measurement height. $g_{\mathrm{a}}$ was calculated flowing Monteith and Unsworth (1990) as follows:

$$
g_{a}=\frac{1}{\frac{u}{u^{* 2}}+6.2 u^{*-0.67}}
$$

where $u$ is wind speed and $u^{\prime \prime}$ is friction velocity.

To calculate the Priestley-Taylor coefficient (LE/LEeq), the equilibrium LE flux $\left(\mathrm{LE}_{\mathrm{eq}}\right)$ was determined using (Priestley and Taylor 1972):

$$
\mathrm{LE}_{e q}=\frac{\Delta\left(R_{n}-G-S\right)}{\Delta+\gamma}
$$

The $L_{\mathrm{eq}}$ is dependent on the $R_{\mathrm{n}}$ and temperature. Lower and higher values indicate evaporation rates that are lower and higher than the equilibrium rate, respectively (Wilson et al. 2002b). The sensitivity of evapotranspiration to stomatal control and the degree of aerodynamic coupling between vegetation and the atmosphere was expressed by the decoupling factor $(\Omega)$, obtained by the equation (Jarvis and McNaughton 1986; Runkle et al. 2014):

$$
\Omega=\frac{\Delta+\gamma}{\Delta+\gamma\left(1+\frac{g_{a}}{g_{c}}\right)}
$$

The value of $\Omega$ ranges from 0 to 1 . When it approaches 0 , the vegetation and the atmosphere are fully aerodynamically coupled and the evapotranspiration proceeds at 
rates imposed by vapor pressure deficit; when it approaches 1 , the vegetation and the atmosphere are completely aerodynamically decoupled and the evapotranspiration is controlled by $R_{\mathrm{n}}$ (Goldberg and Bernhofer 2001).

\section{Results}

\section{Microclimate}

The mean $T_{\mathrm{a}}$ in $2007-2010$ was $8.23,6.83,5.64$, and $7.91^{\circ}$ $\mathrm{C}$, respectively (Table 1 ). For the growing season, the mean $T_{\mathrm{a}}$ in $2007\left(21.26{ }^{\circ} \mathrm{C}\right)$ and $2010\left(20.67{ }^{\circ} \mathrm{C}\right)$ were higher than that in $2008\left(19.76^{\circ} \mathrm{C}\right)$ and $2009\left(19.88^{\circ} \mathrm{C}\right)$. The maximum $T_{\mathrm{a}}$ occurred in July of 2007 and 2008, August of 2009, and June of 2010, while the minimum $T_{\mathrm{a}}$ occurred in January in all 4 years. For the non-growing seasons (October-April) of 2007-2008, 2008-2009, 2009-2010, and 2010-2011, the mean $T_{\mathrm{a}}$ was -2.82 , $-3.38,-6.69$, and $-5.62{ }^{\circ} \mathrm{C}$, respectively. The $T_{\mathrm{s}}$ closely followed the changes of $T_{\mathrm{a}}$ (Fig. 1a). However, there was no significant difference between $T_{\mathrm{s}}\left(21.15{ }^{\circ} \mathrm{C}\right)$ and $T_{\mathrm{a}}\left(21.26{ }^{\circ} \mathrm{C}\right)$ in the growing season of 2007 .
Precipitation amounts and distribution were significantly different during the 4 years. Annual precipitation from 2007 to 2010 was $207.9,384.2,281.5$, and $265.6 \mathrm{~mm}$, respectively. These years can be classified as dry (2007, 2009, and 2010) or wet years (2008) based on to the precipitation trending in the Songnen meadow steppe for the past 50 years (Fig. 2). The driest period was from DOY181 to DOY279 in 2007, with the first rain of $>3 \mathrm{~mm}$. Precipitation or snowfall throughout the initial 6 months was minimal. In 2008, the meadow steppe received $85 \%$ more precipitation and experienced 18 more single precipitation pulses than in 2007. The first precipitation in 2008 (March 22nd) was 3 months earlier than in 2007, and the rainy season therein lasted longer and ended on November 15th. In 2009 and 2010, precipitation started in mid-April, and it ended in mid-October and mid-November, respectively. Total precipitation of March-May in dry year 2007 accounted for only $8.8 \%$ and $5.1 \%$ of that in 2009 and 2010, respectively, indicating that the meadow steppe experienced a serious spring drought in 2007. On the other hand, June-August precipitation was low in 2010

Table 1 Daily means of microclimatic variables and energy balance components during the growing season and non-growing season of 2007-2010 in Songnen meadow steppe

\begin{tabular}{|c|c|c|c|c|c|c|c|c|c|c|c|c|}
\hline & \multicolumn{4}{|c|}{ Growing season } & \multicolumn{4}{|c|}{ Non-growing season } & \multicolumn{4}{|c|}{ Whole year } \\
\hline & \multicolumn{4}{|c|}{ (May-September) } & \multicolumn{4}{|c|}{ (October-April) } & \multirow[b]{2}{*}{2007} & \multirow[b]{2}{*}{2008} & \multirow[b]{2}{*}{2009} & \multirow[b]{2}{*}{2010} \\
\hline & 2007 & 2008 & 2009 & 2010 & 2007 & 2008 & 2009 & $2010^{*}$ & & & & \\
\hline $\mathrm{T}_{\mathrm{a}}\left({ }^{\circ} \mathrm{C}\right)$ & 21.26 & 19.76 & 19.88 & 20.67 & -2.82 & -3.38 & -6.69 & -5.62 & 8.23 & 6.83 & 5.64 & 7.91 \\
\hline $\mathrm{T}_{5}\left({ }^{\circ} \mathrm{C}\right)$ & 21.15 & 17.78 & 16.53 & 16.92 & -0.87 & -1.02 & -2.91 & 0.40 & - & 7.14 & 5.91 & 7.31 \\
\hline $\operatorname{SWC}\left(\mathrm{m}^{3} \mathrm{~m}^{-3}\right)$ & 0.44 & 0.52 & 0.52 & 0.40 & 0.22 & 0.23 & 0.19 & 0.24 & 0.28 & 0.35 & 0.33 & 0.29 \\
\hline VPD (kPa) & 1.23 & 0.92 & 1.10 & 1.16 & 0.37 & 0.34 & 0.25 & 0.28 & 0.77 & 0.60 & 0.65 & 0.72 \\
\hline SWP (bar) & -0.91 & -0.30 & -0.25 & -0.30 & -2.07 & -0.68 & -1.15 & -0.40 & -2.44 & -1.08 & -0.52 & -0.55 \\
\hline Precipitation (mm) & 198.7 & 340.7 & 213.3 & 199.7 & 42.5 & 69.4 & 33.7 & 60.8 & 207.9 & 384.2 & 281.5 & 265.6 \\
\hline $\mathrm{ET}(\mathrm{mm})$ & 287.3 & 326.1 & 317.8 & 339.7 & 71.7 & 90.7 & 104.9 & 100.7 & 334.5 & 403.9 & 401.5 & 453.7 \\
\hline ET/P & 1.45 & 0.96 & 1.52 & 1.70 & 1.69 & 1.31 & 3.11 & 1.66 & 1.61 & 1.05 & 1.43 & 1.71 \\
\hline$R_{n}\left(M J m^{-2} d^{-1}\right)$ & 10.04 & 9.90 & 10.69 & 9.54 & 1.83 & 2.16 & 2.44 & 1.69 & 6.54 & 5.16 & 6.30 & 7.42 \\
\hline LE (MJ $\left.m^{-2} d^{-1}\right)$ & 4.58 & 5.19 & 5.09 & 5.43 & 0.87 & 0.97 & 1.18 & & 3.18 & 2.71 & 2.82 & 3.84 \\
\hline$H\left(\mathrm{MJ} \mathrm{m}^{-2} \mathrm{~d}^{-1}\right)$ & 3.56 & 2.48 & 3.23 & 2.78 & 2.15 & 1.99 & 1.67 & & 2.83 & 2.23 & 2.66 & 2.47 \\
\hline$G\left(M J m^{-2} d^{-1}\right)$ & 1.217 & 0.690 & 1.220 & 0.730 & -0.494 & -0.549 & -0.640 & & 0.356 & 0.041 & -0.034 & 0.240 \\
\hline $\mathrm{S}\left(\mathrm{MJ} \mathrm{m}^{-2} \mathrm{~d}^{-1}\right)$ & 0.007 & 0.002 & 0.003 & 0.008 & -0.011 & -0.006 & -0.007 & & -0.006 & -0.006 & -0.002 & 0.011 \\
\hline$L E / R_{n}$ & 0.46 & 0.53 & 0.46 & 0.51 & 0.12 & 0.18 & 0.19 & & 0.34 & 0.28 & 0.33 & 0.38 \\
\hline$H / R_{n}$ & 0.37 & 0.27 & 0.32 & 0.29 & 0.55 & 0.57 & 0.56 & & 0.39 & 0.40 & 0.48 & 0.46 \\
\hline $\mathrm{G} / \mathrm{R}_{\mathrm{n}}$ & 0.115 & 0.067 & 0.068 & 0.078 & 0.033 & 0.051 & 0.023 & & 0.171 & 0.048 & 0.055 & 0.045 \\
\hline$S / R_{n}$ & -0.003 & -0.005 & -0.007 & -0.002 & -0.022 & -0.015 & -0.017 & & -0.021 & -0.013 & -0.017 & -0.012 \\
\hline EBR & 0.94 & 0.83 & 0.85 & 0.92 & 1.31 & 1.17 & 0.96 & & 1.00 & 0.97 & 0.91 & 0.93 \\
\hline$\beta$ & 1.39 & 0.95 & 1.29 & 1.04 & 5.75 & 4.82 & 3.49 & & 2.83 & 3.47 & 3.05 & 1.97 \\
\hline $\mathrm{LE} / \mathrm{LE}_{\mathrm{eq}}$ & 0.57 & 0.59 & 0.54 & 0.59 & 0.45 & 0.43 & 0.6 & & 0.53 & 0.51 & 0.5 & 0.61 \\
\hline $\mathrm{g}_{c}\left(\mathrm{~mm} \mathrm{~s}^{-1}\right)$ & 4.06 & 6.21 & 4.90 & 5.38 & 2.71 & 2.78 & 5.64 & & 3.45 & 4.34 & 4.22 & 5.92 \\
\hline$\Omega$ & 0.24 & 0.33 & 0.26 & 0.34 & 0.22 & 0.20 & 0.39 & & 0.23 & 0.26 & 0.25 & 0.26 \\
\hline
\end{tabular}

"The data from January-April in 2011 were not available 


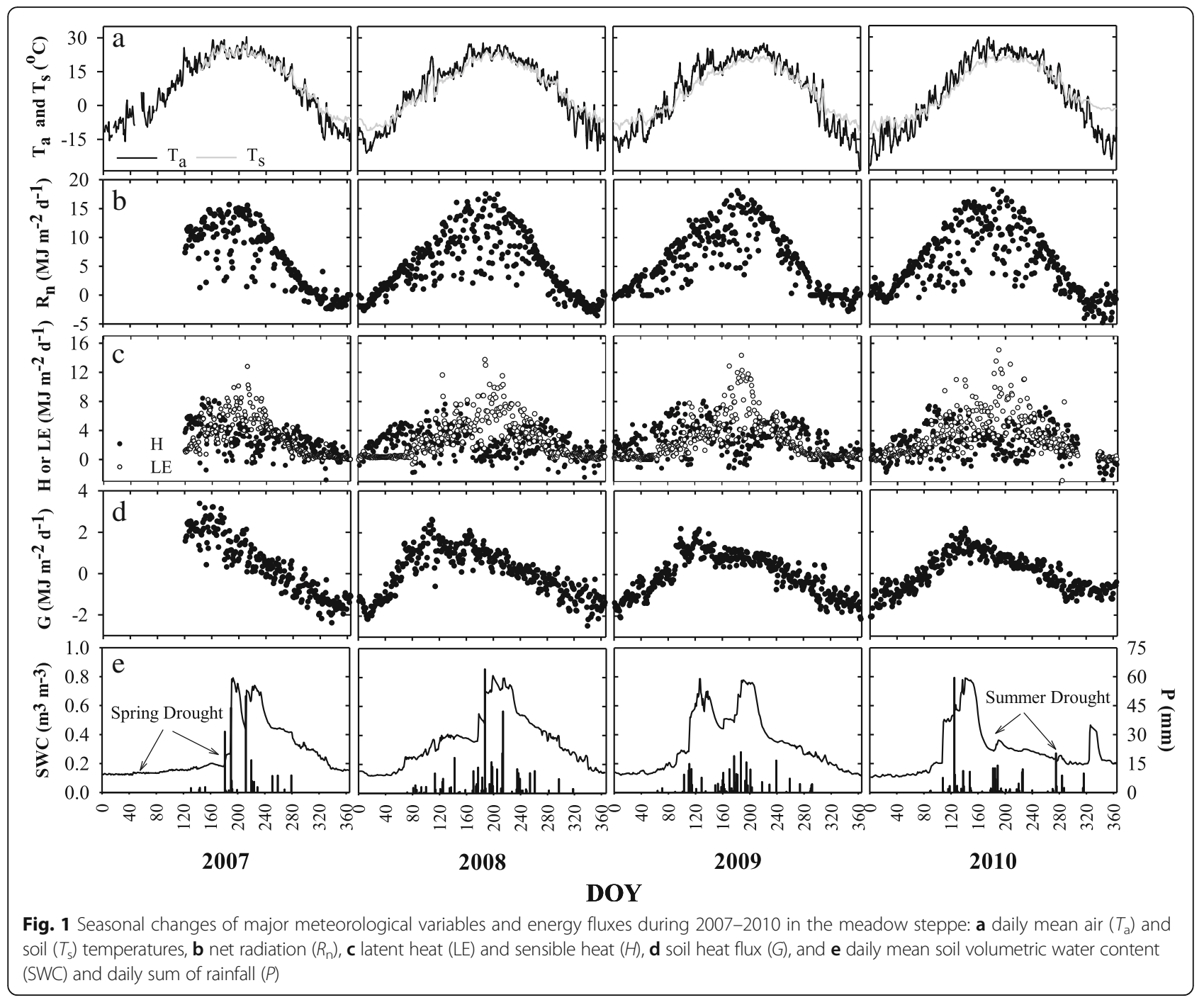

(90.7 $\mathrm{mm})$ compared to that in $2007(170 \mathrm{~mm})$ and 2008 $(231.9 \mathrm{~mm})$. In the meadow steppe, transient waterlogging occurs usually after a single precipitation of $>30 \mathrm{~mm}$, and the waterlogging condition often lasts for 2-3 days. Six transient waterlogging events were detected during the study period: DOY181, 190, 212 in 2007; DOY187, 214 in 2008; DOY125 in 2010.

Seasonal variation of SWC closely followed the changes in precipitation. The temporal change of SWC was clearly asymmetrical within any of the 4 years (Fig. 1e). A long dry period in 2007 resulted in severe water deficit in the spring and early summer when the SWC fell below $0.2 \mathrm{~m}^{3} \mathrm{~m}^{-3}$ in the upper soil layer. In contrast, frequent precipitation events during the summer of 2008 resulted in a consistently higher SWC. The highest SWC occurred in the early spring of 2009 and 2010, which declined sharply afterwards. SWC decreased to its minimum before July in 2010, followed by a summer drought. The SWC recovered in June of 2009 after a series of continuous precipitation events. A large precipitation event combined with several isolated precipitation events led to a temporary SWC peak during the 2010 summer compared to the previous summer. Interestingly, SWC at $10 \mathrm{~cm}$ depth did not drop below $0.4 \mathrm{~m}^{3} \mathrm{~m}^{-3}$ during the water-stressed periods in 2007 and 2009 (Fig. 2).

A unimodal pattern of growing season AGB and LAI showed an overall higher AGB and earlier peak in 2008 than in the dry years (Fig. 3). Peak value of AGB in August 2007 was $~ 68 \%$ of that in July and August of 2009 and 2010. LAI was highest in 2008 and lowest in 2007.

\section{Energy balance closure}

The energy balance enclosures using half-hourly and daily values produced reasonable results for all 4 years (Table 2). The slope of the enclosure was $<1$ for all years, with an average value $( \pm \mathrm{SD})$ of $0.75( \pm 0.06)$, intercept of 10.48 $21.17 \mathrm{~W} \mathrm{~m}^{-2}$, and $R^{2}$ value of $0.84-0.98$. For the growing 


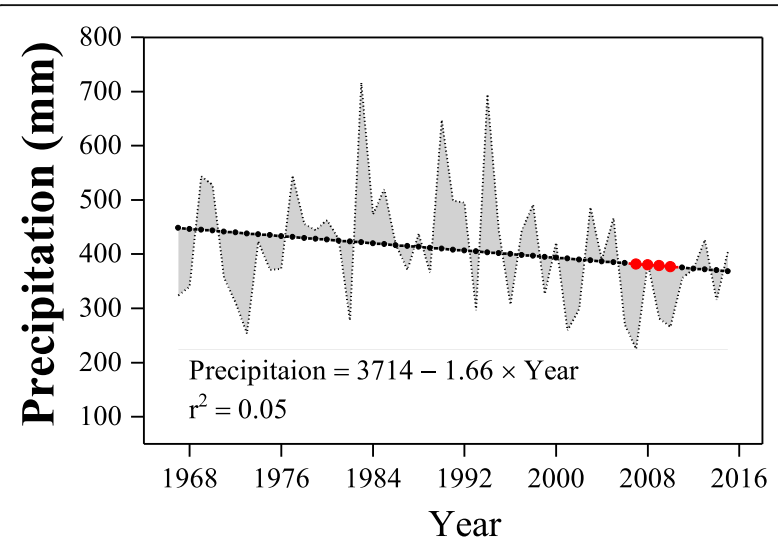

Fig. 2 Long-term change in annual precipitation and its trend in Songnen meadow steppe during the past 49 years (1967 to 2015)

season, the slope values were similar in 2008, 2009, and 2010. The average slope value increased to $0.85( \pm 0.09)$, ranging from 0.74 to 0.93 , when using the daily sums instead of the half-hourly data to calculate the regression coefficients of $[\mathrm{LE}+H]$ against $\left[R_{\mathrm{n}}-G-S\right]$.

The EBR provides an overall evaluation of energy closure at long temporal scale by averaging over random errors in the flux measurement. The mean values of EBR for the four growing seasons were 0.94 (2007), 0.83 (2008), 0.85 (2009), and 0.92 (2010), respectively, and increased to 1.00, 0.97, 0.91, and 0.93 at annual scale for the four consecutive years (Table 1).

\section{Intra- and interannual variations in energy fluxes}

The seasonal changes of daily $R_{\mathrm{n}}, \mathrm{LE}, H$, and $G$ were similar (Fig. 1b-d). $R_{\mathrm{n}}$ showed maximum values of $15.67-$ $20.86 \mathrm{MJ} \mathrm{m}^{-2}$ day $^{-1}$ in July and the minimum values of from - 1.03-3.56 $\mathrm{MJ} \mathrm{m}^{-2}$ day $^{-1}$ in December among the
Table 2 Energy enclosure based on half-hourly and daily sums of the growing seasons during 2007-2010

\begin{tabular}{lllllllllll}
\hline & \multicolumn{3}{l}{ Half-hourly value } & & & Daily value & & \\
\cline { 2 - 3 } \cline { 9 - 10 } & 2007 & 2008 & 2009 & 2010 & & 2007 & 2008 & 2009 & 2010 \\
\hline Slope & 0.84 & 0.70 & 0.73 & 0.74 & & 0.93 & 0.74 & 0.82 & 0.90 \\
Intercept & 10.48 & 4.76 & 16.67 & 21.17 & & 60.82 & 467.6 & 171.94 & 83.24 \\
$r^{2}$ & 0.93 & 0.91 & 0.93 & 0.91 & & 0.83 & 0.72 & 0.81 & 0.85 \\
\hline
\end{tabular}

4 years. Seasonal changes in LE matched well with those of $R_{\mathrm{n}}$, which gradually increased from May, peaked in July-August, and gradually decreased until soil was frozen in late October through February. During the spring drought in 2007, LE in March-May (3.51 MJ m ${ }^{-2}$ day $^{-1}$ ) was $70 \%$ of the normal values $\left(4.65-5.08 \mathrm{MJ} \mathrm{m}^{-2}\right.$ day $\left.^{-1}\right)$. LE during the peak growing season of 2010 (July-August) was $7.31 \mathrm{MJ} \mathrm{m}^{-2}$ day $^{-1}$ and remained lower during 2007$2009\left(\sim 6.4 \mathrm{MJ} \mathrm{m}^{-2}\right.$ day $\left.^{-1}\right)$ despite the summer drought of 2010. Surprisingly, $H$ showed a bimodal seasonal change, which increased at the beginning of a year, peaked in May, and began to decrease in June even though $R_{\mathrm{n}}$ continued its high values. Interestingly, $H$ started to increase again in August and reached the second peak in September. As expected, $G$ values were low, especially during the wintertime. At the beginning of March, $G$ switched from negative to positive and continued to increase, reaching a maximum in May for 2007 (3.39 MJ m ${ }^{-2}$ day $\left.^{-1}\right), 2009$ (2.16 MJ m ${ }^{-2}$ day $\left.^{-1}\right)$, and $2010\left(2.15 \mathrm{MJ} \mathrm{m}^{-2} \mathrm{day}^{-1}\right)$, but in June of 2008 $\left(2.10 \mathrm{MJ} \mathrm{m}^{-2}\right.$ day $\left.^{-1}\right)$.

Monthly LE value was higher than $H$ value during the growing season in 2008 (Fig. 4). In dry years, the duration of higher LE over $H$ appeared short (2 months) in 2007 (spring drought), mediate (3 months) in 2009, and long (4 months) in 2010, with different starting days

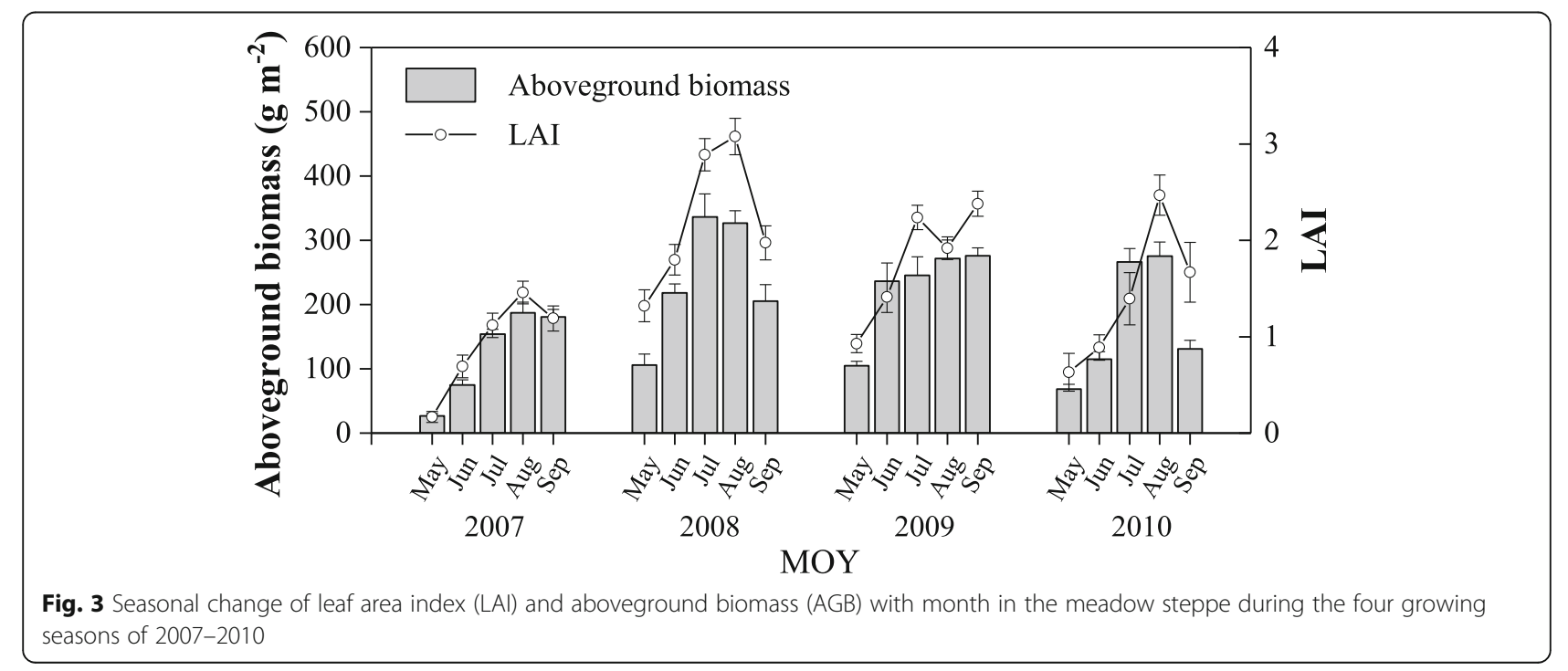




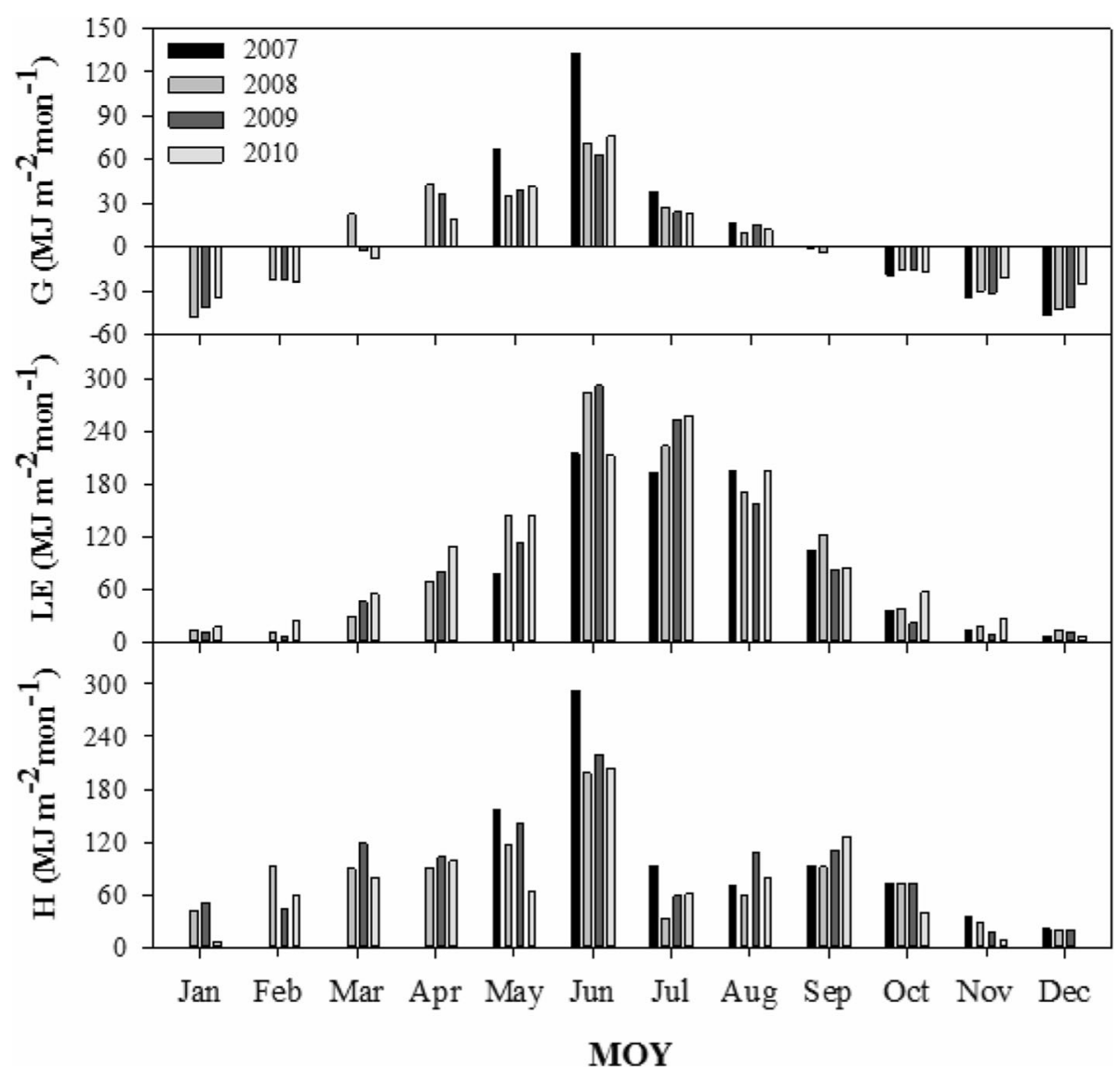

Fig. 4 The monthly change of latent heat (LE), sensible heat $(H)$, and soil heat flux $(G)$ during 2007-2010 in the Songnen meadow steppe in northeastern China

in July, June, and May, respectively. For accumulated G, however, a positive $G\left(22.72 \mathrm{MJ} \mathrm{m}{ }^{-2}\right.$ month $\left.^{-1}\right)$ was observed in March 2008, which was $-2.00 \mathrm{MJ} \mathrm{m}^{-2}$ month $^{-1}$ in 2009 and $-7.84 \mathrm{MJ} \mathrm{m}^{-2}$ month $^{-1}$ in 2010. More importantly, $G$ in May $\left(67.91 \mathrm{MJ} \mathrm{m}^{-2}\right.$ month $\left.^{-1}\right)$ and June (132.91 MJ m ${ }^{-2}$ month $^{-1}$ ) of 2007 was about twice the values of $2008\left(35.21 / 71.93 \mathrm{MJ} \mathrm{m}{ }^{-2}\right.$ month $\left.^{-1}\right), 2009$ (39.85/63.93 MJ m ${ }^{-2}$ month $\left.^{-1}\right)$, and 2010 (41.44/ 76.21 MJ m ${ }^{-2}$ month $^{-1}$ ).

Sensible heat $(H)$ was a major factor of $R_{\mathrm{n}}$ at annual scale, but LE was more influential during the growing seasons, with the mean $\mathrm{LE} / R_{\mathrm{n}}$ ratio 0.46 to 0.53 . $\mathrm{LE} / R_{\mathrm{n}}$ values remained low during the non-growing season, with mean values in $0.12,0.18$, and 0.19 for 2007,2008 , and 2009, respectively (Table 1 ). The peak $\mathrm{LE} / R_{\mathrm{n}}$ in 2007 arrived half a month later than that in 2010 (Fig. 5). Throughout the spring drought period in $2007, L E / R_{n}$ remained low until late summer. In contrast, $L E / R_{\mathrm{n}}$ in 2010 remained relatively high from the beginning of the growing season, when soil moisture was high due to the large precipitation input. The seasonal changes of $H / R_{\mathrm{n}}$ seemed to be a mirror image of $\mathrm{LE} / R_{\mathrm{n}}$ in all 4 years. The lowest value of $H / R_{\mathrm{n}}$ was observed during the growing season when $L E / R_{\mathrm{n}}$ was the highest, while $H / R_{\mathrm{n}}$ began increasing in late September. The annual mean $G / R_{\mathrm{n}}$ was higher in $2007(0.171)$ than in other years $(0.0045-$ 0.055 ) (Table 1). Although there was a higher $G / R_{\mathrm{n}}$ at the beginning of growing season (May-June) in 2007, no significant difference was found among LEs of the 4 years despite a severe summer drought in July-August of 2010.

\section{Biophysical controls of energy partitioning}

The Bowen ratio $(\beta, H / \mathrm{LE})$ during the growing season varied from 0.21 to 4.63 (Fig. 6b). Due to a faster increase in $H$ than that in LE during the spring, midday means of $\beta$ over the growing season exhibited a concave shape, with $\beta$ being $>1$ during spring and autumn, but $\sim 1$ in summer. Over the growing season, midday means of $\beta$ amounted to $1.39,0.95,1.29$, and 1.04 for $2007-$ 2010, respectively. The low LE and high $H$ during the non-growing season resulted in a dramatic increase in the mean daytime $\beta$. Mean daily $\beta$ varied from 0.02 to 12.85 over the 4-year study period, with the largest value found in the non-growing season of 2007 (DOY310), and the lowest in the growing season of 2010 (DOY233). 


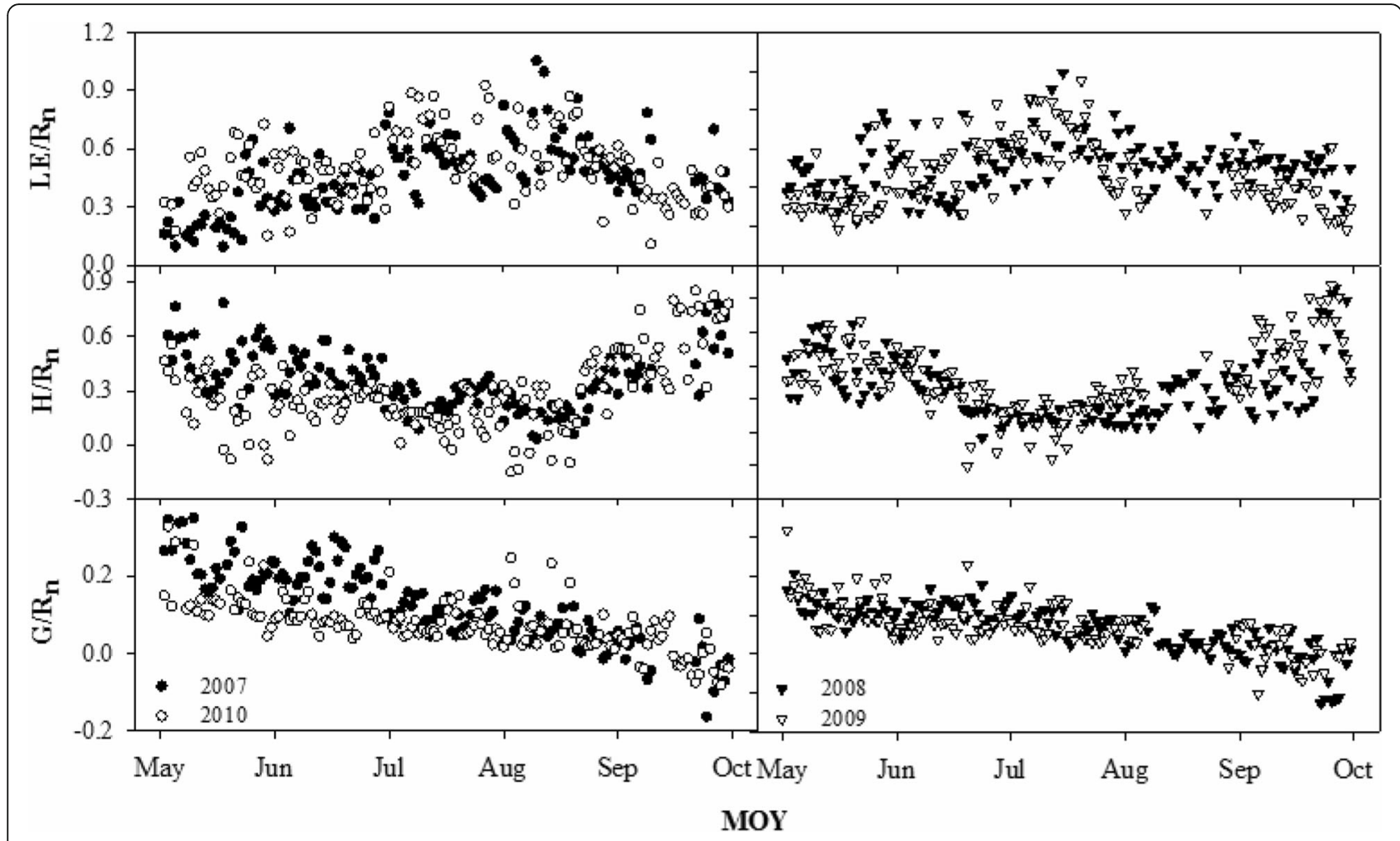

Fig. 5 Growing season fractions of latent heat, sensible heat, and soil heat flux to net radiation (LE/Rn, $H / R_{n}, G / R_{n}$, respectively) during 2007-2010

The average of daily $\beta$ during the spring drought period was 1.97 , which was higher than that in the summer drought period (1.17). The $g_{c}$ value ranged from 0.02 to $19.67 \mathrm{~mm} \mathrm{~s}^{-1}$ during the growing season, with a peak in July of 2008, 2009, and 2010, but not in 2007, when the maximum $g_{c}$ was delayed to August (Fig. 6c). In 2007, LAI maintained a higher level after July while $g_{\mathrm{c}}$ declined during the same time. During the growing season, the $\Omega$ value amounted a peak of 0.73 (DOY229), 0.81 (DOY214), 0.75 (DOY204), and 0.56 (DOY213), respectively, for the 4 years. Its seasonal changes appeared less pronounced compared to other measures of the fluxes, with the change in 2007 very different from that in other 3 years (Fig. 6).

\section{Discussion}

Impact of precipitation intensity on water and energy balance

In this study, $P$ and ET appeared to be more or less balanced in the wet year. Differing from previous reports on $P$ vs ET in neighboring typical steppes on the Mongolia Plateau (Chen et al. 2009; Foken et al. 2006), the meadow steppe in our study showed an overall higher cumulative ET than cumulative $P$ in dry years (2007, 2009, and 2010), suggesting there were other sources of water to enrich the soil (Fig. 7). The mean annual ET $(409.5 \mathrm{~mm})$ (Table 1) in the meadow steppe lies in the higher end of ET values $(163 \sim 481 \mathrm{~mm})$ for grasslands worldwide (Aires et al. 2008; Krishnan et al. 2012; Li et al. 2007; Ryu et al. 2008; Zha et al. 2010). However, ET (334.5 mm) in 2007-a spring drought-fell below the mean value. The ratio of ET/P varied between 1.05 and 1.71 for all study years (Table 1 ), and was higher than those in the Mediterranean grasslands (0.4-0.87) (Aires et al. 2008; Ryu et al. 2008), American semi-arid prairies (0.72-1.20) (Krishnan et al. 2012), northern temperate grasslands (0.98) (Hao et al. 2007; Wever et al. 2002), and alpine Kobresia meadows (0.60) (Li et al. 2013), but similar to those in the alpine wetland meadows (1.27) (Hu et al. 2009).

Intensity of precipitation events had a crucial effect on water-energy balance and ecosystem recovery after drought (Cabral et al. 2010; Heisler-White et al. 2008; Knapp et al. 2008). Differences in seasonal ET/P in the meadow steppe suggested that non-growing season $P$ from snow would supplement water resources required for the following growing season. The relative contribution of temporally isolated non-growing season precipitation events to water availability in the next growing season is considered a critical determinant of ecological processes (Eamus et al. 2001; Ma et al. 2013). Previous studies have indicated that freezing and thawing have important influences on ET and surface energy fluxes (Chen et al. 2011; Gu et al. 2005; Yao et al. 2008), by 


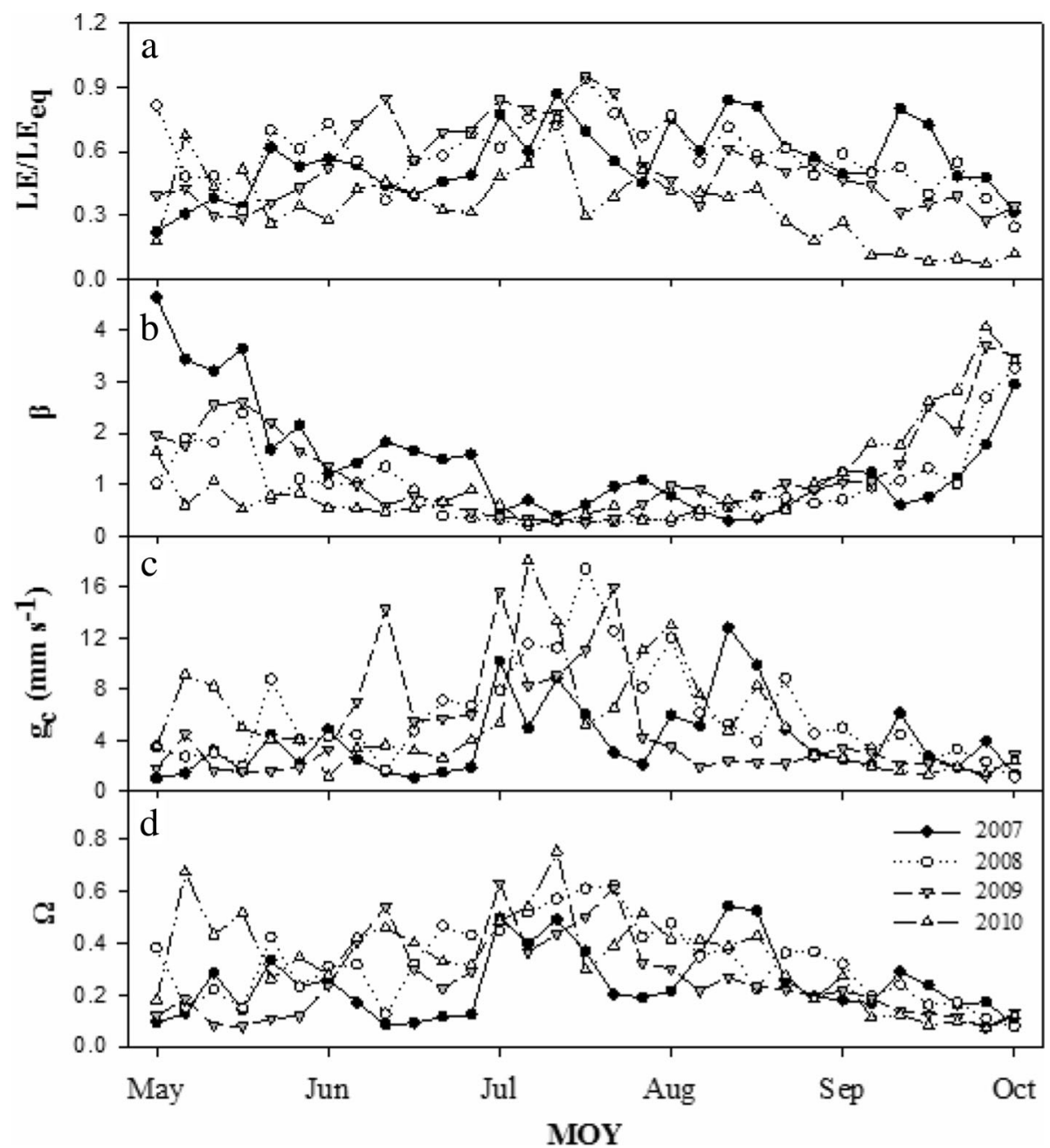

Fig. 6 The seasonal change of 5-day average midday $L E / L E_{\text {eq, }}$ Bowen ration $(\beta)$, canopy conductance $\left(g_{c}\right)$, and decoupling coefficient $(\Omega)$ in four study years in the meadow steppe. Midday means were calculated for 10:00-15:00 h

increasing SWC and ET from melted snow and frozen soil (Zhang et al. 2014; Zhang et al. 2003). Although cumulative $P$ was lower than ET at annual scale, the monthly $P$ could sometimes be higher than ET in the meadow steppe during the growing season. For example, heavy and frequent precipitation events in July of 2008 brought $\sim 132.66 \mathrm{~mm}$ precipitation and $90.8 \mathrm{~mm}$ ET at our site, yielding a peak soil water content of 0.91 . Similarly, although the maximum soil water content was equivalent to that of 2008, $P$ was $86.5 \%$ lower and ET was $13.8 \%$ higher following the consecutive precipitation events in July 2009 compared to those in July 2008 (Figs. 1 and 7), suggesting a proportion of precipitation infiltrated to recharge groundwater in 2008. Heavy precipitation events in May $2010(P=105.1 \mathrm{~mm}$, $\mathrm{ET}=58.4 \mathrm{~mm}$ ) alleviated summer drought in the growing season through water infiltration into deep soil under similar maximum soil water content $(0.89 \mathrm{~mm})$ in May $2009(P=14.5 \mathrm{~mm}, \mathrm{ET}=45.6 \mathrm{~mm})$. Therefore, AGB between 2009 and the summer drought year of 2010 remained similar, likely because both the low infiltration rate in the alkali-saline soil of the meadow steppe and the limited precipitation input from short and sporadic showers could substantially reduce soil moisture. However, low ET/P in July 2007 (0.74), in July (0.68), and August (0.68) of 2008 and in May 2010 (0.56) (Fig. 7) indicated that infiltration might have happened after occasional and large precipitation events (Knapp et al. 2008; Thomey et al. 2011).

In our study, LE was apparently influenced by the process of temporary waterlogging caused by precipitation $>30 \mathrm{~mm}$ in a day (Fig. 8). LE increased because of low vegetation cover and high groundwater level at the beginning of the growing season, which is consistent with the findings of spring drought influence on evapotranspiration and water use efficiency in the same steppe (Dong et al. 2011). However, LE declined in response to the 3-day waterlogging at 


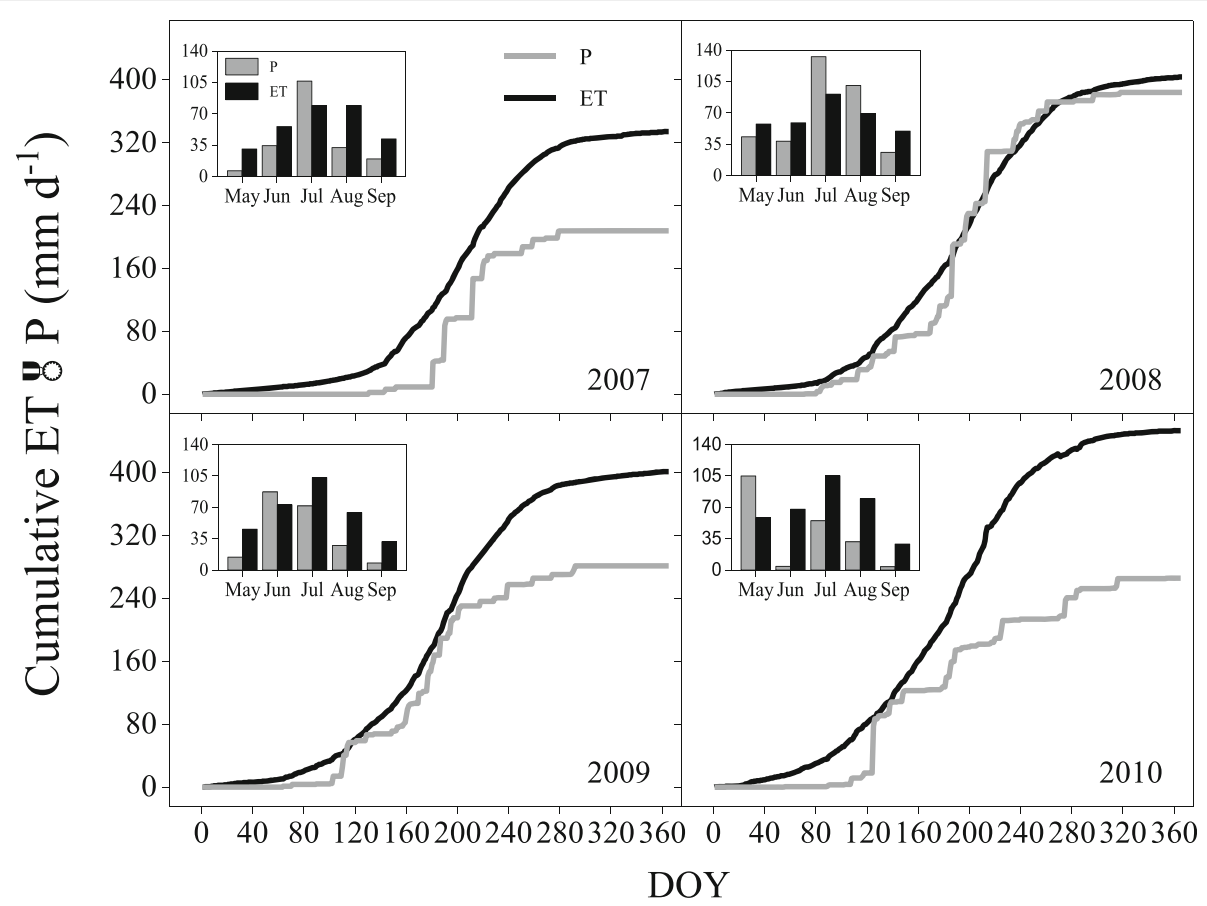

Fig. 7 The annual and monthly accumulation of precipitation (P) (gray) and evapotranspiration (ET) (black) for the Songnen meadow steppe during 2007-2010

the growing season peak of 2007 and 2008, which could possibly be attributed to stomatal closure and reduction in both leaf photosynthesis and root respiration. Clearly, the severity of waterlogging effects on LE depend on the developmental stage of the grass.
Influence of drought on energy balance and partitioning The Songnen meadow steppe exhibited the great intraand interannual variability of energy partitioning into $H$ and LE, which also differed greatly between the dry and wet years. The meadow steppe was LE-dominated when

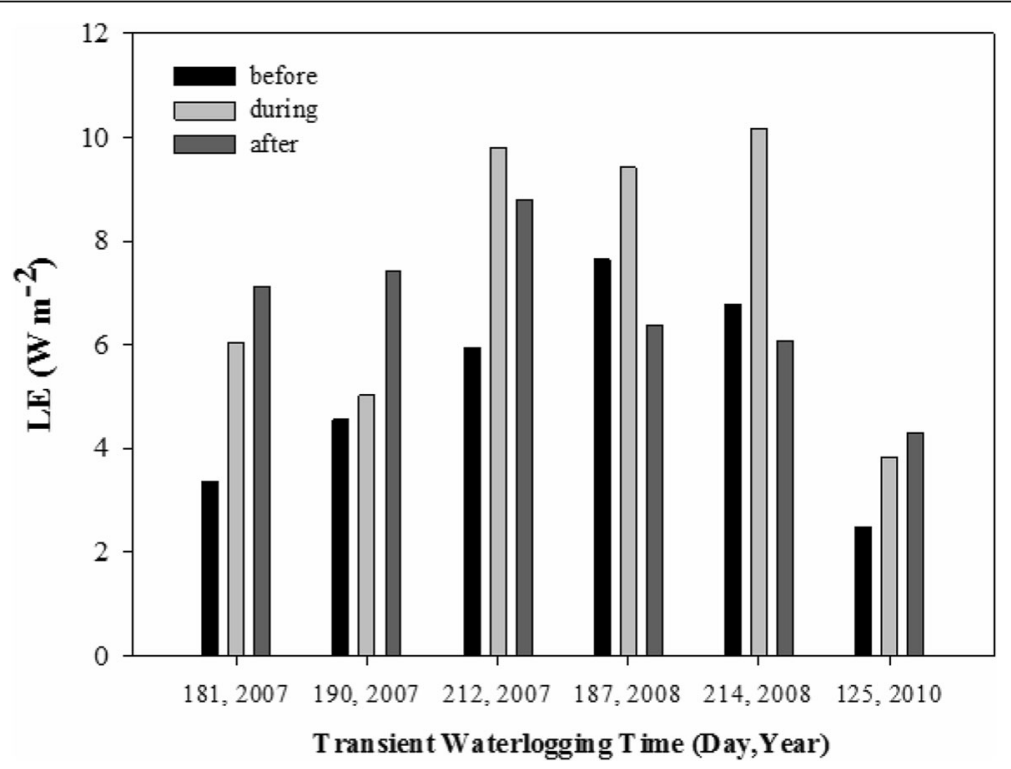

Fig. 8 The magnitudes of latent heat (LE) before, during (3-day), and after the transient waterlogging during 2007-2010 
soil water content was $>0.3 \mathrm{~m}^{3} \mathrm{~m}^{-3}$, but switched to $H$-dominated status when soil water content fell below $0.3 \mathrm{~m}^{3} \mathrm{~m}^{-3}$ (Fig. 9). The timing of the shift from an $H$-dominated to a LE-dominated energy balance depended on the magnitude of the first precipitation event $\left(>30 \mathrm{~mm} \mathrm{day}^{-1}\right.$ ) or accumulated precipitation within five consecutive days over $30 \mathrm{~mm}$, which enabled grass seed germination with SWC exceeding $0.3 \mathrm{~m}^{3} \mathrm{~m}^{-3}$. Similarly, the switch from a LE-dominated to an $\mathrm{H}$-dominated ecosystem happened in concert with the start of biomass senescence when SWC fell below $0.3 \mathrm{~m}^{3} \mathrm{~m}^{-3}$. However, LE was dominant in energy balance even though SWC dropped to $0.3 \mathrm{~m}^{3} \mathrm{~m}^{-3}$ in the growing season of 2010 (since DOY200), which likely was due to the lag effect of a large precipitation event at early stage. In 2008-2010, the change in energy partitioning occurred in May-June. However, the spring drought led to a shift from $H$ to LE occurring in mid-July in 2007. The increase in SWC and vegetation growth during the growing season altered solar heating of the surface via a decrease in albedo that likely was driven by the dark soil and vegetation surfaces after the precipitation events (Krishnan et al. 2012; Thompson et al. 2004).
Interannual climate, especially the occurrence, duration, and extent of drought, can significantly reduce LE in this site. On the one hand, limited precipitation could cause a decrease in soil moisture and limit soil water recharge, thus decreasing LE. On the other hand, droughts with high temperature and radiation would result in a reduction in transpiration with lower stomatal conductance of foliage and canopy (Chen et al. 2009). For instance, spring drought in 2007 resulted in a higher LE over $H$ in the beginning of growing season (May-June), but the summer drought of 2010 did not change the interannual relation of higher LE over $H$ in June-August. The growth of plants was triggered by the monsoon precipitation for all grasses. Delayed and low LE in spring drought year appeared to be a direct consequence of slow grass germination and late starting of transpiration. The main reason for higher LE during summer drought meanwhile might be related to the soil water availability. Several large precipitation pulses at the beginning of the growing season could have replenished the soil profile to allow grass to reach a biomass peak despite the summer drought in 2010. The results suggested that LE was more sensitive to spring drought than to summer

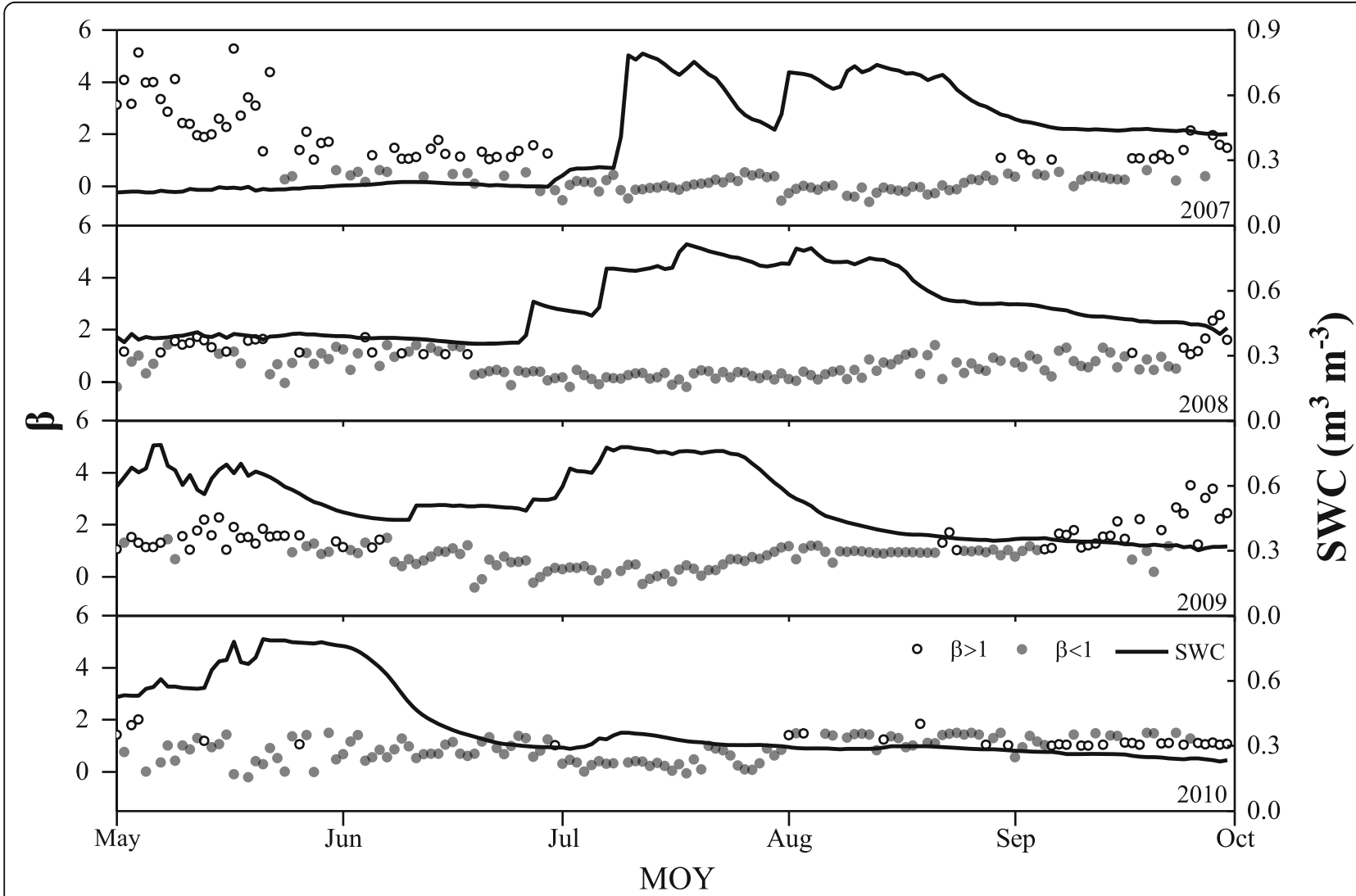

Fig. 9 Daily mean soil volumetric water content (SWC) and daily mean Bowen ration ( $\beta$ ) in the meadow steppe during the four growing seasons of 2007-2010 
drought, and there was hardly a negative consequence of summer drought to LE in the meadow steppe.

Impacts of biotic and climate on LE were further examined for other flux terms and key parameters, including $\mathrm{LE} / \mathrm{LE}_{\mathrm{eq}}, g_{\mathrm{c}}$, and $\Omega$. Evapotranspiration (i.e., latent heat) is mainly composed of plant transpiration $\left(T_{\mathrm{r}}\right)$, soil evaporation $\left(E_{\mathrm{s}}\right)$, and the negligible proportion of canopy intercepted precipitation $(I)$ in grasslands that can be inferred from $\mathrm{LE} / \mathrm{LE}_{\mathrm{eq}}, g_{c}$, and $\Omega$. LE/LE $\mathrm{Lq}_{\text {eq }}$ is conventionally used to estimate daily evapotranspiration (Wilson et al. 2002a). LE/LE ef spring drought (0.53) and summer drought $(0.61)$ in this study were typical events for the semi-arid grassland $L E / L_{\text {eq }}(0.6-0.7)$ (Meyers 2001), indicating that the restriction of the water supply for LE over the meadow steppe was less compared to other grasslands. Decreased $g_{\mathrm{c}}$ is usually attributed to low LAI during the growing season (Baldocchi et al. 2004) and decreasing stem-root hydraulic conductivity under conditions of low soil water content (Rodrigues et al. 2013). According to Dong et al. (2011), $E_{\mathrm{s}}$ was significantly higher than $T_{\mathrm{r}}$ under spring drought conditions, during which $E_{\mathrm{s}}$ released more than $85 \%$ of available soil water in May 2007. During the spring drought period, the low $g_{\mathrm{c}}$ did not reflect the low transpiration rate. On the contrary, higher $g_{c}$ during summer drought may have been influenced by high LAI in 2007. $\Omega$ evaluated the response of LE to air humidity and net radiation changes (Jarvis and Mcnaughton 1986). $\Omega$ of growing seasons was higher in summer drought (0.34) than in spring drought (0.24), suggesting that LE was highly sensitive to decreasing air humidity. Moreover, similar $\Omega(0.33)$ in summer drought years and wet years further proved the significant effect of spring drought in increasing sensitivity of LE to low air humidity. In summary, although LE was not limited by water stress in the meadow steppe $\left(4.58 \mathrm{MJ} \mathrm{m}^{-2}\right.$ day $^{-1}$ in spring drought and $5.43 \mathrm{MJ} \mathrm{m}$ day $^{-1}$ in summer drought), spring drought had an even stronger effect on LE than summer drought did.
The proportion of individual surface energy balance component is a result of complex, long-term interactions between biogeochemical cycling, disturbance and climate, as well as short-term interactions of plant physiology and the dynamics of the atmospheric boundary layer (Aires et al. 2008; Baldocchi et al. 2004; Shao et al. 2012; Sun et al. 2010). The annual values of $L E / R_{\mathrm{n}}$ in our study $(0.28$ 0.40 ) are comparable to the $0.31-0.35$ that were reported for an annual grassland (Baldocchi et al. 2004), but lower than those in a tallgrass prairie $(0.48-0.58)$ (Burba and Verma 2005) and in a Mediterranean $C_{4}$ grassland (0.37-0.55) (Jongen et al. 2011). For the growing season, $\mathrm{LE} / R_{\mathrm{n}}(0.49)$ was similar to that in an alpine meadow ( $\mathrm{Li}$ et al. 2013), and higher than in temperate semi-arid grasslands in North America (Krishnan et al. 2012) and $C_{3} / C_{4}$ grassland in Southern Portugal (Aires et al. 2008), but less than the values reported in the Mongolian steppe (Li et al. 2007). When compared among the 4 years, the spring drought in 2007 caused the highest $H / R_{\mathrm{n}}$ and $G / R_{\mathrm{n}}$ but the lowest $L E / R_{\mathrm{n}}$. The short-term water deficit at the initial stage of growing season could be partially responsible for the low LAI and AGB values. The cumulative available energy was $639.8 \mathrm{MJ} \mathrm{m}^{-2}$ in the extended drought period of 2010 (July-August), 6.6\% lower than that of the same month in 2007. However, there was no obvious decrease in $\mathrm{LE} / R_{\mathrm{n}}$ (Fig. 5), suggesting that the magnitude of LE was not constrained by the availability of energy but rather by the vegetation cover at dry period. As a result of earlier water inputs from precipitation, grass germinated earlier in the season, and the growing period was lengthened to maintain a stable and high AGB.

Soil heat flux $(G)$ played an important role in energy partitioning at our site, which is similar to previous findings at other typical steppes (e.g., Shao et al. 2008). Soil heat flux tended to increase with $R_{\mathrm{n}}$ and $H$. A low canopy cover in the spring drought year jointly led to the highest $G$ values $\left(0.356 \mathrm{MJ} \mathrm{m}^{-2}\right.$ day $\left.^{-1}\right)$. Other than for the spring drought year, $G / R_{\mathrm{n}}$ was $<0.1$ at the

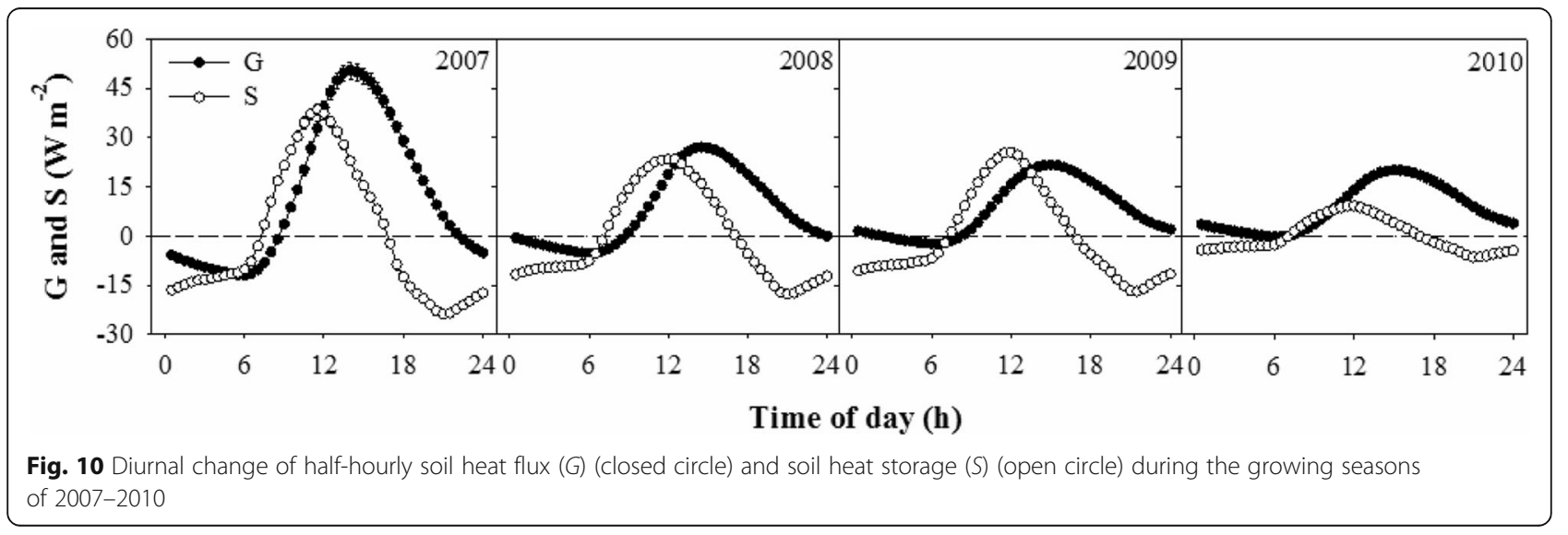


meadow steppe, which was lower than those reported in other grasslands (Aires et al. 2008) but similar to those at the Mongolian steppe and temperate semi-arid prairies (Krishnan et al. 2012; Li et al. 2007). More importantly, soil heat flux had wider diel variations in the dry year of 2007 than in other years (Fig. 10). The large seasonal fluctuations also reflected the seasonal variation in soil thermal conductivity, which were regulated by precipitation, soil moisture, and seasonal changes in vegetation coverage that directly determine value $R_{\mathrm{n}}$ (Heusinkveld et al. 2004; Rodrigues et al. 2013). A higher $G$ was expected in a wet year (2008) because soil thermal conductivity increased with soil moisture (Hillel et al. 2005). However, the shading effect of vegetation cover likely offset the positive effect of soil thermal conductivity and resulted in lower $G\left(0.69 \mathrm{MJ} \mathrm{m}^{-2}\right.$ day $\left.^{-1}\right)$. Finally, a higher $S$ was found in spring drought year. A critical take-home message is that, if $S$ is omitted from our analysis, $G$ value at the topsoil may underestimate the surface heat flux by $>50 \%$ at our site (Ochsner et al. 2007; Shao et al. 2008).

The lack of energy closure is a common feature in most eddy flux sites. According to the FLUXNET study (Wilson et al. 2002a), the EBR for all vegetation types of site-years ranged from 0.53 to 0.99 , with a mean of $0.79 \pm$ 0.01 . For the ChinaFLUX sites, the annual EBR ranged from 0.58 to 1.00, with a mean of 0.83 (Chen et al. 2011). In this study, the mean energy imbalance $(0.89 \pm 0.05)$ at meadow steppe is generally within, or higher than, the acceptable range reported within the FLUXNET and ChinaFLUX sites, which was higher compared with typical steppe $0.83 \pm 0.07$ (Chen et al. 2009).

\section{Conclusions}

Changes in precipitation resulted in frequent drought and waterlogging in meadow steppe of northeastern China. We measured the energy and water fluxes over a meadow steppe in Songnen Plain over a 4-year study period and found that spring and summer droughts resulted in a rapid shift in energy partitioning due to the change of water availability. However, spring drought produced more severe effects than summer drought. The rise of the groundwater level in our study region usually followed a large precipitation event or a series of continuous precipitation pulses that have profound influence on ecosystem water balance. Waterlogging influenced LE by enhancing its values during and after the waterlogged periods at the beginning of growing season in a dry year, but lowering them after the waterlogged periods in growing season. Disentangling the roles of different water table heights in controlling the energy balance, particularly LE remains a challenging research topic and should be prioritized in future studies.

\section{Abbreviations}

AGB: Aboveground biomass; EBR: Energy balance ratio; EC: Eddy-covariance; $E_{s}$ : Soil evaporation; ET: Evapotranspiration; G: Soil heat flux; $g_{c}$ : Canopy conductance; H: Sensible heat flux; LAI: Leaf area index; LE: Latent heat; $L_{\text {eq: }}$ : Equilibrium LE flux; P: Precipitation; PAR: Photosynthetically active radiation; $R_{\mathrm{h}}$ : Relative humidity; $R_{\mathrm{n}}$ : Net radiation; S: Heat storage; SWC: Soil water content; SWP: Soil water potential; $T_{\mathrm{a}}$ : Air temperature; $T_{\mathrm{r}}$ : Plant transpiration; $T_{s}$ : Soil temperature profiles; VPD: Vapor pressure deficit; Vt: Vegetation height; WD: Wind direction; WPL: Webb-Pearman-Leaning; WS: Wind speed; $\beta$ : Bowen ratio; $\Omega$ : Decoupling factor

\section{Acknowledgements}

This study was supported by the Major State Research Development Program of China (2016YFC0500600, 2017YFE0104500), Natural Science Foundation of China (31800512, 31870466), and the US-China Carbon Consortium (USCCC). We are grateful to all members who worked at the Changling station. Sincere thanks go to Ge Sun, Jingfeng Xiao, and Haiqiang Guo for their useful comments and valuable suggestions on early versions of the manuscript. We also greatly appreciate the careful reviews by the anonymous reviewers and editing of Kristine Blakeslee.

\section{Availability of data and materials}

The datasets generated and/or analyzed during the current study are available from the corresponding author upon request.

\section{Authors' contributions}

$J Y C, C L S$, and GD constructed the overall structure of the manuscript. JYC and $C L S$ analyzed the data and wrote the paper. SCJ and LPQ contributed the assistance with data collection and fieldwork. CLS, GD, and FYZ guided and revised the content. All authors read and approved the final manuscript.

Ethics approval and consent to participate

Not applicable.

Consent for publication

Not applicable.

\section{Competing interests}

The authors declare that they have no competing interests.

\section{Publisher's Note}

Springer Nature remains neutral with regard to jurisdictional claims in published maps and institutional affiliations.

\section{Author details}

${ }^{1}$ Institute of Loess Plateau, Shanxi University, Taiyuan 030006, China. ${ }^{2}$ National Hulunber Grassland Ecosystem Observation and Research Station \& Institute of Agricultural Resources and Regional Planning, Chinese Academy of Agricultural Sciences, Beijing 100081, China. ${ }^{3}$ Key Laboratory of Vegetation Ecology, Ministry of Education, Northeast Normal University, Changchun 130024, China. ${ }^{4}$ Forestry Post-Doctoral Station, Forest Ecology Stable Isotope Center, Forestry College, Fujian Agriculture and Forestry University, Fuzhou 350002, China. ${ }^{5}$ Institute of Applied Ecology, Chinese Academy of Sciences, Shenyang 110016, China. ${ }^{6}$ University of Chinese Academy of Sciences, Beijing 100049, China. ${ }^{7}$ School of Life Science, Shanxi University, Taiyuan 030006,

China.

Received: 12 March 2019 Accepted: 24 April 2019

Published online: 25 May 2019

\section{References}

Aires LM, Pio CA, Pereira JS (2008) The effect of drought on energy and water vapour exchange above a mediterranean $C_{3} / C_{4}$ grassland in Southern Portugal. Agric For Meteorol 148(4):565-579

Baldocchi DD, Xu L, Kiang N (2004) How plant functional-type, weather, seasonal drought, and soil physical properties alter water and energy fluxes of an oak-grass savanna and an annual grassland. Agric For Meteorol 123(1-2):13-39

Burba GG, Verma SB (2005) Seasonal and interannual variability in evapotranspiration of native tallgrass prairie and cultivated wheat ecosystems. Agric For Meteorol 135(1-4):190-201 
Cabral OMR, Rocha HR, Gash JHC, Ligo MAV, Freitas HC, Tatsch JD (2010) The energy and water balance of a Eucalyptus plantation in southeast Brazil. J Hydrol 388(3-4):208-216

Chen J, Wan S, Henebry G, Qi J, Gutman G, Sun G, Kappas M (2013) Dryland East Asia: land dynamics amid social and climate change. Higher Education Press, Beijing

Chen N, Guan D, Jin C, Wang A, Wu J, Yuan F (2011) Influences of snow event on energy balance over temperate meadow in dormant season based on eddy covariance measurements. J Hydrol 399(1-2):100-107

Chen S, Chen J, Lin G, Zhang W, Miao H, Wei L, Huang J, Han X (2009) Energy balance and partition in Inner Mongolia steppe ecosystems with different land use types. Agric For Meteorol 149(11):1800-1809

Dong G, Guo J, Chen J, Sun G, Gao S, Hu L, Wang Y (2011) Effects of spring drought on carbon sequestration, evapotranspiration and water use efficiency in the songnen meadow steppe in Northeast China. Ecohydrology 4(2):211-224

Eade R, Hamilton E, Smith DM, Graham RJ, Scaife AA (2012) Forecasting the number of extreme daily events out to a decade ahead. J Geophys Res Atmos. https://doi.org/10.1029/2012JD018015

Eamus D, Hutley LB, O'Grady AP (2001) Daily and seasonal patterns of carbon and water fluxes above a north Australian savanna. Tree Physiol 21(12-13):977-988

Falge E, Baldocchi D, Olson R, Anthoni P, Aubinet M, Bernhofer C, Burba G, Ceulemans R, Clement R, Dolman H, Granier A, Gross P, Grunwald T, Hollinger D, Jensen NO, Katul G, Keronen P, Kowalski A, Lai CT, Law BE, Meyers T, Moncrieff $H$, Moors E, Munger JW, Pilegaard K, Rannik U, Rebmann C, Suyker A, Tenhunen J, Tu K, Verma S, Vesala T, Wilson K, Wofsy S (2001) Gap filling strategies for long term energy flux data sets. Agric For Meteorol 107(1):71-77

Feng X, Fu B, Piao S, Wang S, Ciais P, Zeng Z, Lü Y, Zeng Y, Li Y, Jiang X (2016) Revegetation in China's Loess Plateau is approaching sustainable water resource limits. Nat Clim Chang 6(11):1019-1022

Foken T, Wimmer F, Mauder M, Thomas C, Liebethal C (2006) Some aspects of the energy balance closure problem. Atmos Chem Phys 6(12):4395-4402

Goldberg V, Bernhofer C (2001) Quantifying the coupling degree between land surface and the atmospheric boundary layer with the coupled vegetationatmosphere model HIRVAC. Ann Geophys 19(5):581-587

Groisman P, Shugart H, Kicklighter D, Henebry G, Tchebakova N, Maksyutov S, Monier E, Gutman G, Gulev S, Qi J, Prishchepov A, Kukavskaya E, Porfiriev B, Shiklomanov A, Loboda T, Shiklomanov N, Nghiem S, Bergen K, Albrechtová J, Chen J, Shahgedanova M, Shvidenko A, Speranskaya N, Soja A, Kd B, Bulygina O, McCarty J, Zhuang Q, Zolina O (2017) Northern Eurasia Future Initiative (NEFI): facing the challenges and pathways of global change in the twenty-first century. Prog Earth Planetary Sci 4(1):41

Gu S, Tang Y, Cui X, Kato T, Du M, Li Y, Zhao X (2005) Energy exchange between the atmosphere and a meadow ecosystem on the Qinghai-Tibetan Plateau. Agric For Meteorol 129(3-4):175-185

Hao Y, Wang Y, Huang X, Cui X, Zhou X, Wang S, Niu H, Jiang G (2007) Seasonal and interannual variation in water vapor and energy exchange over a typical steppe in Inner Mongolia, China. Agric For Meteorol 146(1-2):57-69

Heisler-White J, Knapp A, Kelly E (2008) Increasing precipitation event size increases aboveground net primary productivity in a semi-arid grassland. Oecologia 158(1):129-140

Heusinkveld BG, Jacobs AFG, Holtslag AAM, Berkowicz SM (2004) Surface energy balance closure in an arid region: role of soil heat flux. Agric For Meteorol 122(1-2):21-37

Hillel D, Hatfield JH, Powlson DS, Rosenzweig C, Scow KM, Singer MJ, Sparks DL (2005) Thermal properties and processes. In: H Daniel (ed) Encyclopedia of Soils in the Environment. Elsevier, Oxford, pp 156-163

Hu Z, Yu G, Zhou Y, Sun X, Li Y, Shi P, Wang Y, Song X, Zheng Z, Zhang L, Li $S$ (2009) Partitioning of evapotranspiration and its controls in four grassland ecosystems: application of a two-source model. Agric For Meteorol 149(9):1410-1420

IPCC (2013) Summary for policymakers. In: Climate change 2013: the physical science basis. Cambridge University Press, New York, pp 1-30

Jaeger WK, Amos A, Bigelow DP, Chang H, Conklin DR, Haggerty R, Langpap C, Moore K, Mote PW, Nolin AW (2017) Finding water scarcity amid abundance using human-natural system models. Proc Natl Acad Sci U S A 114(45):11884-11889

Jarvis PG, McNaughton KG (1986) Stomatal control of transpiration: scaling up from leaf to region. Adv Ecol Res 15:1-49

Jongen M, Pereira JS, Aires LMI, Pio CA (2011) The effects of drought and timing of precipitation on the inter-annual variation in ecosystem-atmosphere exchange in a Mediterranean grassland. Agric For Meteorol 151(5):595-606
Knapp AK, Beier C, Briske DD, Classen AT, Luo Y, Reichstein M, Smith MD, Smith SD, Bell JE, Fay PA (2008) Consequences of more extreme precipitation regimes for terrestrial ecosystems. BioScience 58(9):811-821

Krishnan P, Meyers TP, Scott RL, Kennedy L, Heuer M (2012) Energy exchange and evapotranspiration over two temperate semi-arid grasslands in North America. Agric For Meteorol 153:31-44

Li J, Jiang S, Wang B, Jiang W-w, Tang Y-h, Du M-y, Gu S (2013) Evapotranspiration and its energy exchange in alpine meadow ecosystem on the Qinghai-Tibetan Plateau. J Integr Agric 12(8):1396-1401

Li S-G, Asanuma J, Kotani A, Davaa G, Oyunbaatar D (2007) Evapotranspiration from a Mongolian steppe under grazing and its environmental constraints. J Hydrol 333(1):133-143

Ma X, Huete A, Yu Q, Coupe NR, Davies K, Broich M, Ratana P, Beringer J, Hutley LB, Cleverly J, Boulain N, Eamus D (2013) Spatial patterns and temporal dynamics in savanna vegetation phenology across the North Australian Tropical Transect. Remote Sens Environ 139:97-115

Meyers TP (2001) A comparison of summertime water and $\mathrm{CO}_{2}$ fluxes over rangeland for well watered and drought conditions. Agric For Meteorol 106(3):205-214

Minderlein S, Menzel L (2015) Evapotranspiration and energy balance dynamics of a semi-arid mountainous steppe and shrubland site in Northern Mongolia. Environ Earth Sci 73(2):1-17

Monier E, Kicklighter DW, Sokolov AP, Zhuang Q, Sokolik IN, Lawford R, Kappas M, Paltsev SV, Groisman PY (2017) A review of and perspectives on global change modeling for Northern Eurasia. Environ Res Lett 12(8):083001

Monteith JL, Unsworth MH (1990) Principles of environmental physics, 2nd edn. Edward Arnold, New York

Ochsner TE, Sauer TJ, Horton R (2007) Soil heat storage measurements in energy balance studies. Agron J 99(1):311

Priestley CHB, Taylor RJ (1972) On the assessment of surface heat flux and evaporation using large-scale parameters. Mon Weather Rev 100(2):81-92

Qi J, Xin X, John R, Groisman P, Chen J (2017) Understanding livestock production and sustainability of grassland ecosystems in the Asian Dryland Belt. Ecol Process 6(1):22

Rey A, Oyonarte C, Morán-López T, Raimundo J, Pegoraro E (2017) Changes in soil moisture predict soil carbon losses upon rewetting in a perennial semiarid steppe in SE Spain. Geoderma 287:135-146

Rodrigues TR, de Paulo SR, Novais JWZ, Curado LFA, Nogueira JS, de Oliveira RG, Lobo FA, Vourlitis GL (2013) Temporal patterns of energy balance for a Brazilian tropical savanna under contrasting seasonal conditions. Int J Atmos Sci https://doi.org/10.1155/2013/326010

Runkle BRK, Wille C, Gažovič M, Wilmking M, Kutzbach L (2014) The surface energy balance and its drivers in a boreal peatland fen of northwestern Russia. J Hydrol 511:359-373

Ryu Y, Baldocchi DD, Ma S, Hehn T (2008) Interannual variability of evapotranspiration and energy exchange over an annual grassland in California. J Geophys Res Atmos 113(D9):D09104

Shao C, Chen J, Li L, Xu W, Chen S, Gwen T, Xu J, Zhang W (2008) Spatial variability in soil heat flux at three Inner Mongolia steppe ecosystems. Agric For Meteorol 148(10):1433-1443

Shao C, Chen J, Li L, Zhang L (2012) Ecosystem responses to mowing manipulations in an arid Inner Mongolia steppe: an energy perspective. J Arid Environ 82:1-10

Shao C, Li L, Dong G, Chen J (2014) Spatial variation of net radiation and its contribution to energy balance closures in grassland ecosystems. Ecol Process 3(1):7

Soja AJ, Groisman PY (2018) Earth science and the integral climatic and socioeconomic drivers of change across northern Eurasia: the NEESPI legacy and future direction. Environ Res Lett 13(4):040401

Sun G, Noormets A, Gavazzi MJ, McNulty SG, Chen J, Domec JC, King JS, Amatya DM, Skaggs RW (2010) Energy and water balance of two contrasting loblolly pine plantations on the lower coastal plain of North Carolina, USA. For Ecol Manag 259(7):1299-1310

Thomey ML, Collins SL, Vargas R, Johnson JE, Brown RF, Natvig DO, Friggens MT (2011) Effect of precipitation variability on net primary production and soil respiration in a Chihuahuan Desert grassland. Glob Chang Biol 17(4):1505-1515

Thompson CC, Beringer J, Chapin FS, Mcguire AD (2004) Structural complexity and land-surface energy exchange along a gradient from arctic tundra to boreal forest. J Veg Sci 15(3):397-406 
Wang Y, Zhou G, Wang Y (2007) Modeling responses of the meadow steppe dominated by Leymus chinensis to climate change. Clim Chang 82(3-4):437452

Webb EK, Pearman Gl, Leuning R (1980) Corrections of flux measurements for density effects due to heat and water vapor transfer. Q J Roy Meteor Soc 106(447):85-100

Wever LA, Flanagan LB, Carlson PJ (2002) Seasonal and interannual variation in evapotranspiration, energy balance and surface conductance in a northern temperate grassland. Agric For Meteorol 112(1):31-49

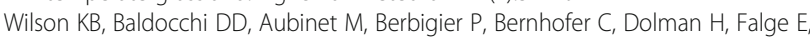
Field C, Goldstein A, Granier A, Grelle A, Halldor T, Hollinger D, Katul G, Law BE, Lindroth A, Meyers T, Moncrieff J, Monson R, Oechel W, Tenhunen J, Valentini R, Verma S, Vesala T, Wofsy S (2002a) Energy partitioning between latent and sensible heat flux during the warm season at FLUXNET sites. Water Resour Res 38(12):1294-1305

Wilson KB, Goldstein AH, Falge E, Aubinet M, Baldocchi DD, Berbigier $P$, Bernhofer C, Ceulemans R, Dolman H, Field CB (2002b) Energy balance closure at FLUXNET sites. Agric For Meteorol 113(1):223-243

Yao J, Zhao L, Ding Y, Gu L, Jiao K, Qiao Y, Wang Y (2008) The surface energy budget and evapotranspiration in the Tanggula region on the Tibetan Plateau. Cold Reg Sci Technol 52(3):326-340

Zha T, Barr AG, van der Kamp G, Black TA, McCaughey JH, Flanagan LB (2010) Interannual variation of evapotranspiration from forest and grassland ecosystems in western Canada in relation to drought. Agric For Meteorol 150(11):1476-1484

Zhang S-Y, Li X-Y, Ma Y-J, Zhao G-Q, Li L, Chen J, Jiang Z-Y, Huang Y-M (2014) Interannual and seasonal variability in evapotranspiration and energy partitioning over the alpine riparian shrub Myricaria squamosa Desv. on Qinghai-Tibet plateau. Cold Reg Sci Technol 102:8-20

Zhang Y, Ohata T, Kadota T (2003) Land-surface hydrological processes in the permafrost region of the eastern Tibetan Plateau. J Hydrol 283(1):41-56

\section{Submit your manuscript to a SpringerOpen ${ }^{\circ}$ journal and benefit from:}

- Convenient online submission

- Rigorous peer review

- Open access: articles freely available online

High visibility within the field

- Retaining the copyright to your article

Submit your next manuscript at $\boldsymbol{\nabla}$ springeropen.com 